\title{
トカマクの導体シエルにギャップが ある場合の補正について
}

\author{
吉川允二・藤沢 登 \\ 松田慎三郎, 大和春海 ${ }^{*}$ (原研)
}

(昭和 46 年 9 月 7 日受理 )

\section{Abstract}

Two methods are discussed in correcting field errors at the the azimuthal shell gans in Tokamak devices. In the first the correction is made by means of hoop currents located concentrically outside the plasma ring. In the second a correction coil is placed at each shell gap. A straightforward procedure that leads to the design of these correct on coils is dest cribed. In the present design procedure the image current on the shell induced by the correction coil current is fully taken into consideration.

\#) On leave from Tokyo Shibaura Electric Company

\section{1 まえがを}

トカマクには通常ブラズマの平衡と安定性の考虑から,導体シエルがブラズマを取り巻くよ5 に置かれている。とのシエルには、ブラズマ中の電流を誘起するためのワンターン電圧を短絡し ないように, 短周に沿って，カットが設けられている。シエルの厚みは，表皮の厚みより大きい。 このため, シェルの内面にはブラズマ電流の鏡像電流が , ブラズマ電流と逆方向に流れ, シエル の外面にはっそのリターンとしてブラズマ電流と順方向に電流が流れる。

実際の装置では, 実験上の便宜のため, 短周に沿ってのカットの輻を広げ, 測定用のギャッブ として用いている。ギャッブの幅过通常 $10 \mathrm{~cm}$ 程度である。ギャッブの附近では, シエル表面上 の電流分布が乱され，磁場の乱れを作る。1),2) との乱れ磁場は，一般にポロイダル成分を持っ

ON THE CORRECTION OF FIELD ERRORS AT SHELL GAPS IN TOKAMAK DEVICES

M. Yoshikawa, N. Fujisawa, S. Matsuda, and H. Yamato

*）東芝総合研究所 


\section{トカマクの導体シェルにギャッブがある場合の補正につけて}

ているのて，回転変換角いが $2 \pi \mathrm{r} / \mathrm{m}$ の条件老满す有理磁気面附近で, 磁気面の「島」を作

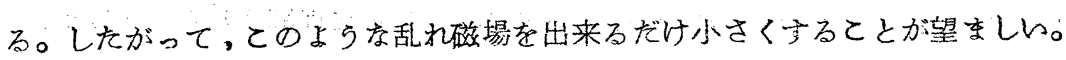

こてでは, 乱れ磁埸補正コイルについての二つの考台方につんて述へる。一は補正コイル自身が, トーラスと同じ軸対称性を持つ場合であり，二法補正コイルが，ギャッブ附近のタに稘かれる嚗合 である。とのような方法については，ての䦗題を考えたととのある方々には自明のとととる思われ るが，原研クルーブ内で討論のあったととでもすり，父似た事情忙他のプラズマ洼置でも遭遇する ととろであるので, 述へて置く。これらの力法ては, 補正コイルを流礼る電流が、シエル表面上 に㮇起する鏡像電流を考慮に入れているととを予为注意しておく。

2 問題の設定
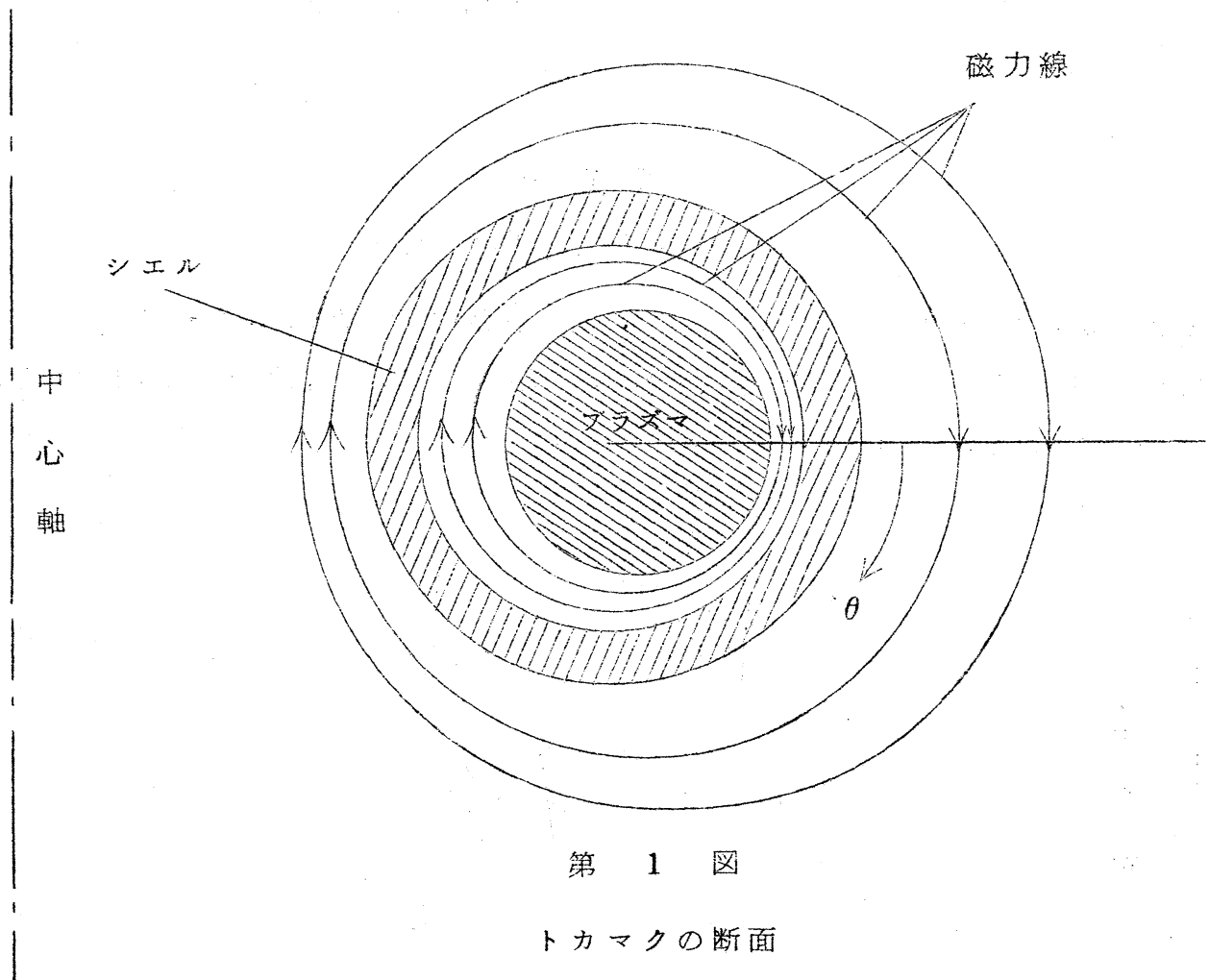

第 1 図

トカマクの断面

第1図に,トカマクの断面を示す。ブラズマつ位置は, 必ずしもシエルの中心にあるとは限ら ないので, 同図では誇張して外側に寄っている場合を描いてある。シエルの内面及び外面を流れ 
吉川 ・ 藤沢 ·松田 · 大和

る表面電流は，表面上で一様ではなく，副方位角 $\theta$ に関する分布は第 2 図に示すようになる。この 電流分布は，第1図に示したシェル附近の磁力線の分布から，定性的に理解されるであるら。

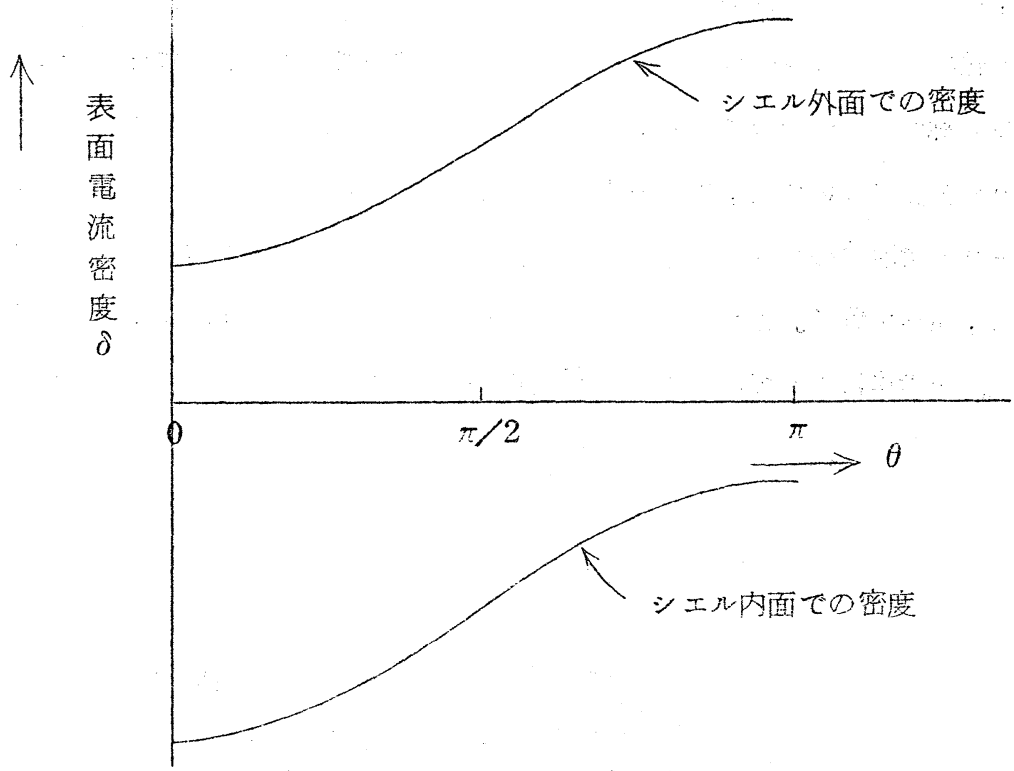

第 2 図

シエル表面上の麗流密度

雪流分布が, 内面と外面とで一致しないのて, 霞流の保存則を满すために, ギャッブの切り口上に

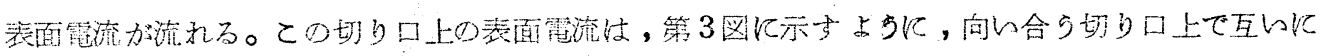
逆力向であるので，ポロイダル成分を持つ乱れ磁場が出来る。
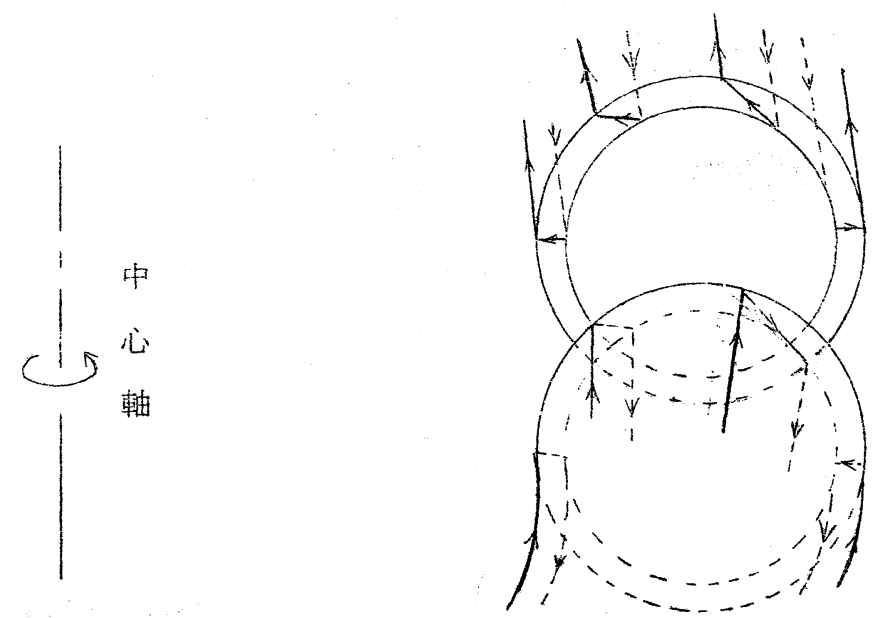

第 3 図 シェル表面上の電流分布 
トカマクの導体シエルにギャッブがある場合の補正について

さて，との乱れ磁埸を補正するとはどのよらにすればよいであるらか。てれについて，以下の節 で考える。

3 シエル外部に置かれたリンク状コイルによる補正

この問題を考え易くするために，まず次のようなモデルをたてる。第 4 图のように二重シエル 構造考考える。

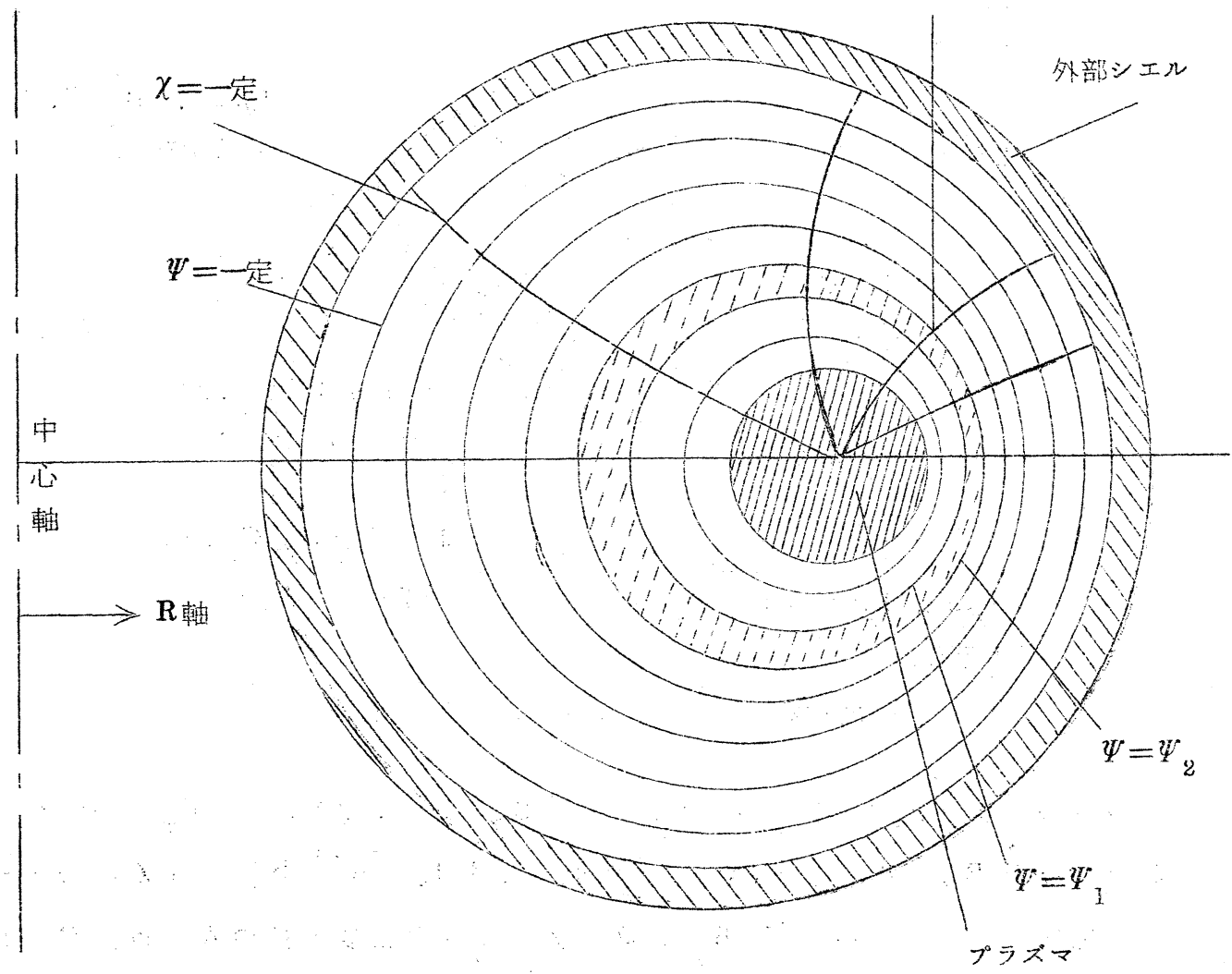

第 4 図 二重シエル構造による補正

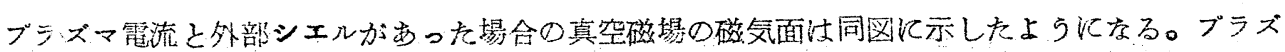
マの平衡注，磁気面群が外側に押し付河らることによって保たれている。この真空磁場を（ $\Psi$, $\chi, \varphi)$ 座標で表わした場合，磁気面は $\Psi=$ 一定 で表わされ，線要素 ds は

$$
\mathrm{d} \mathrm{s}^{2}=\frac{\mathrm{d} \Psi^{2}}{\mathrm{R}^{2} \mathrm{~B}^{2} \chi}+\frac{\mathrm{d} \chi^{2}}{\mathrm{~B}^{2} \chi}+\mathrm{R}^{2} \mathrm{~d} \varphi^{2}
$$

で表わされる。 
吉川 . 藤沢 · 松田 · 大和

さて,てのブラズマ電流と外部シエルで定められる真空磁場中にギャッブ付を内部シエルを次の ようには好込む一内部シェルの表面は $\Psi=\Psi_{1}, \Psi=\Psi_{2}$, 及び $\varphi=\varphi_{1}, \varphi=\varphi_{2}$ 即ち, 内部 シエルは,るとすとの磁気面に沿っており,但し $\varphi=\varphi_{1}$ と $\varphi=\varphi_{2}$ にって決められる切り口 がある。この様子は第五図炕示す。

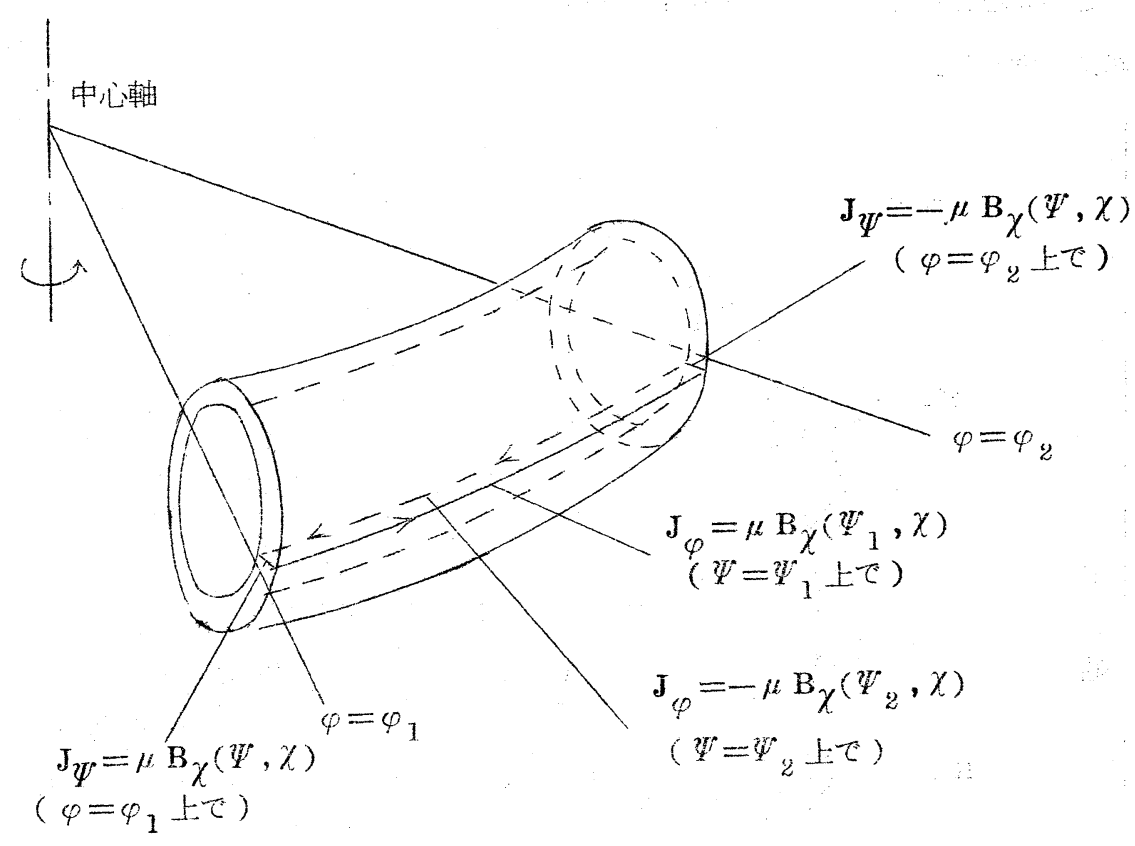

第5图シエル上,切り上上わ表面霓流分布

この場合， $\phi=\psi_{1}$ の表面で㳉 $J_{\varphi}=\mu^{-1} \mathrm{~B} \chi\left(\phi_{1}, \chi\right), \phi=\phi_{2}$ の表面では

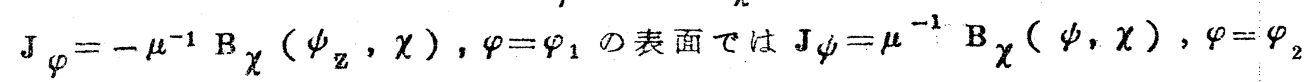

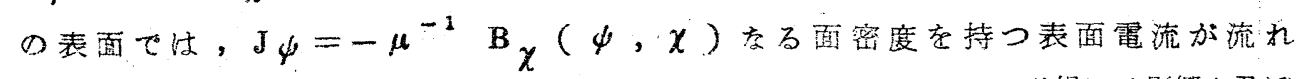

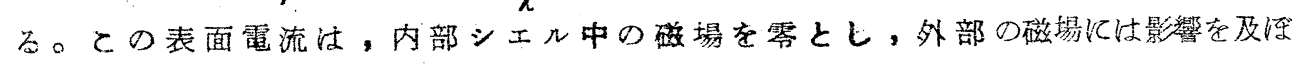
さず，表面での境界条件を満し，表面電流の保存勋を满す解となっている。上を示す過程のうち， や〉自明でないのは $\varphi=\varphi_{1}\left(\right.$ 或いは $\varphi=\varphi_{2}$ ) の表面上での電流の保存則である。てれは次のよ らにして示される。式(1)上り，

$\varphi_{1}+\varepsilon$

$\int_{\varphi_{1}-\varepsilon} \operatorname{Rd} \varphi \operatorname{divj}=\int \operatorname{Rd} \varphi \mathrm{B}^{2} \chi \frac{\partial}{\partial \Psi}\left(\frac{\mathrm{Rj}_{\Psi}}{\mathrm{B}_{\chi}}\right)=\mathrm{R} \mathrm{B}_{\chi}{ }^{2} \frac{\partial}{\partial \Psi} \frac{\mathrm{J}_{\Psi}}{\mathrm{B}_{\chi}}=0$ 


$$
\text { トカマクの導体シエルKギャッブがある場合の補正につんて }
$$

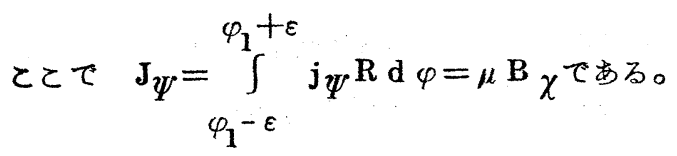

外部シエルの作用は、リング状コイル群によって近似されらる。従って次のよらな結諭が得ら れる。外部に補正リング状コイルを配置し，そてにブラズマ電流に同期した電流を流し，真空磁 気面に沿ったギャップのあるシエルを置けば,ギャッブのために磁場が乱れるととはない。

\section{4 シエル附近に局部的に置かれた補正コイル}

2で述べよらに、ギャッブ附近ではポロイダル磁埥がブラズマにか心る。従って，ての附近 にのみ, 補正用のコイルを配置すれ壮よかろう。しかし、補正コイル中を流れる電流の鏡像電流 がシエル中に誘起される和それがある。以下では, 考光ちとしてどのよう補正コイルを罪けげ

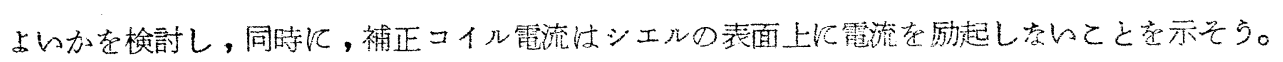
今, 第3図に示したギャッブに, 再び短いシエルを牥込んだとしょ5。(第6図)

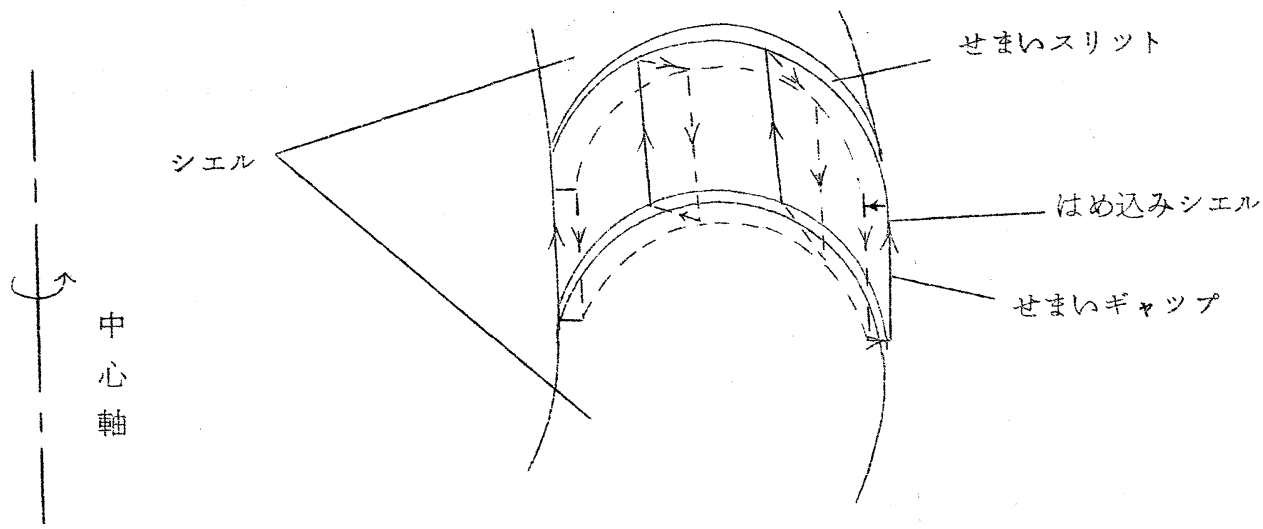

第6図 第3図に壮边みシェルを入れ园，

はめ込みシエル表面上の笔流分布を示す。

このはめ込みシエルと,もともとのシエルの間には, 無限に狭いギャッブををだ残して置くるの とする。はめ込みシエルの表面を流れる電流は第6図に示されている。その $\theta$ 一方向の分有は第 2 図に示されている。従って, 第6図て示されたような雷流分布を近似的に補正コイルで作って やれば、電流分布、及び磁場分布はるとのまをである。

てのような補正電流分布はすう少し実際にやり易い形にるって行くととが出来る。そのためには， 
吉川 • 藤沢 · 松田 . 大和

任意のトロイド上に表面電流を流し，その内部のみ磁埸を作り，外部には全く洩れないよらにする ことがでをるととに注意する。特に第 7 図のような磁場配位が第 8 図に模式的に示した電流分布に 上って作るととが出来る。

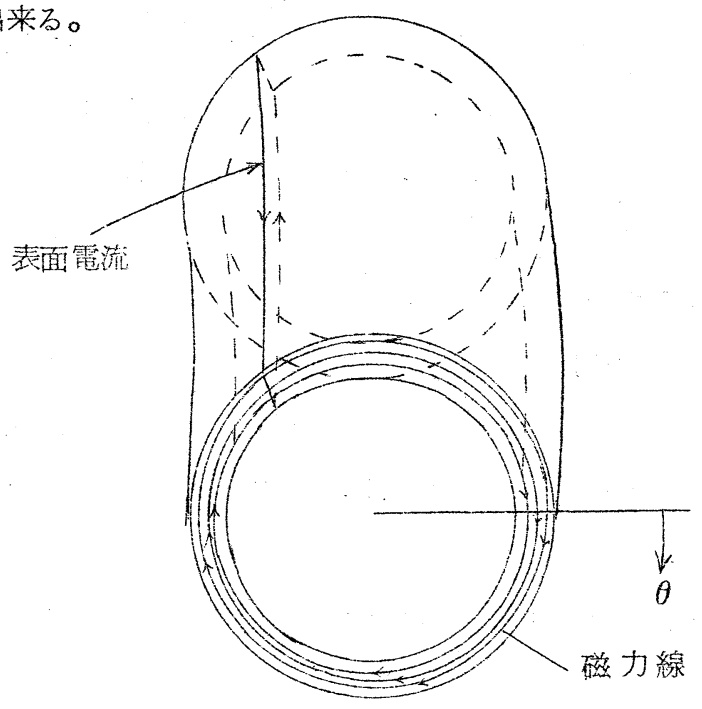

第7图シエル状トロイドの中に限られて存在方磁境の

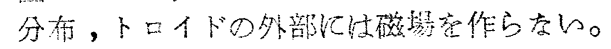

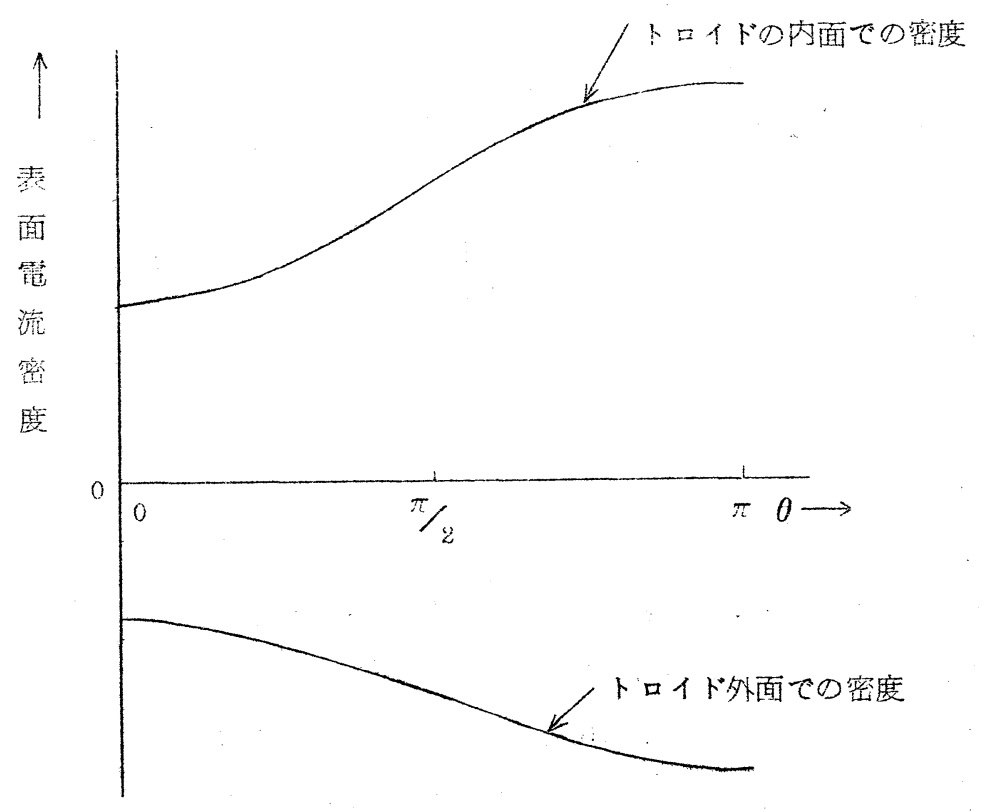

第 8 図トロイト表面上の電流密度 


\section{トカマクの導体シェルKギャップがある場合の補正につレて}

この電流分布は外部は全く磁境を作らないので,シェル表面に新らたに電流を誘起しない。従っ て, 第 2 図の電流分布之第 8 図の電流分布老加えて出来方電流分布（第 9 図，第 10 図）は，補 正コイルで取り曲をれたシエル状の空間を別とすれば，磁埸の分布を全く変えないし，シエル表 面上の電流分布も変えない。との意味で，との補正雫流分布ば理想的である。
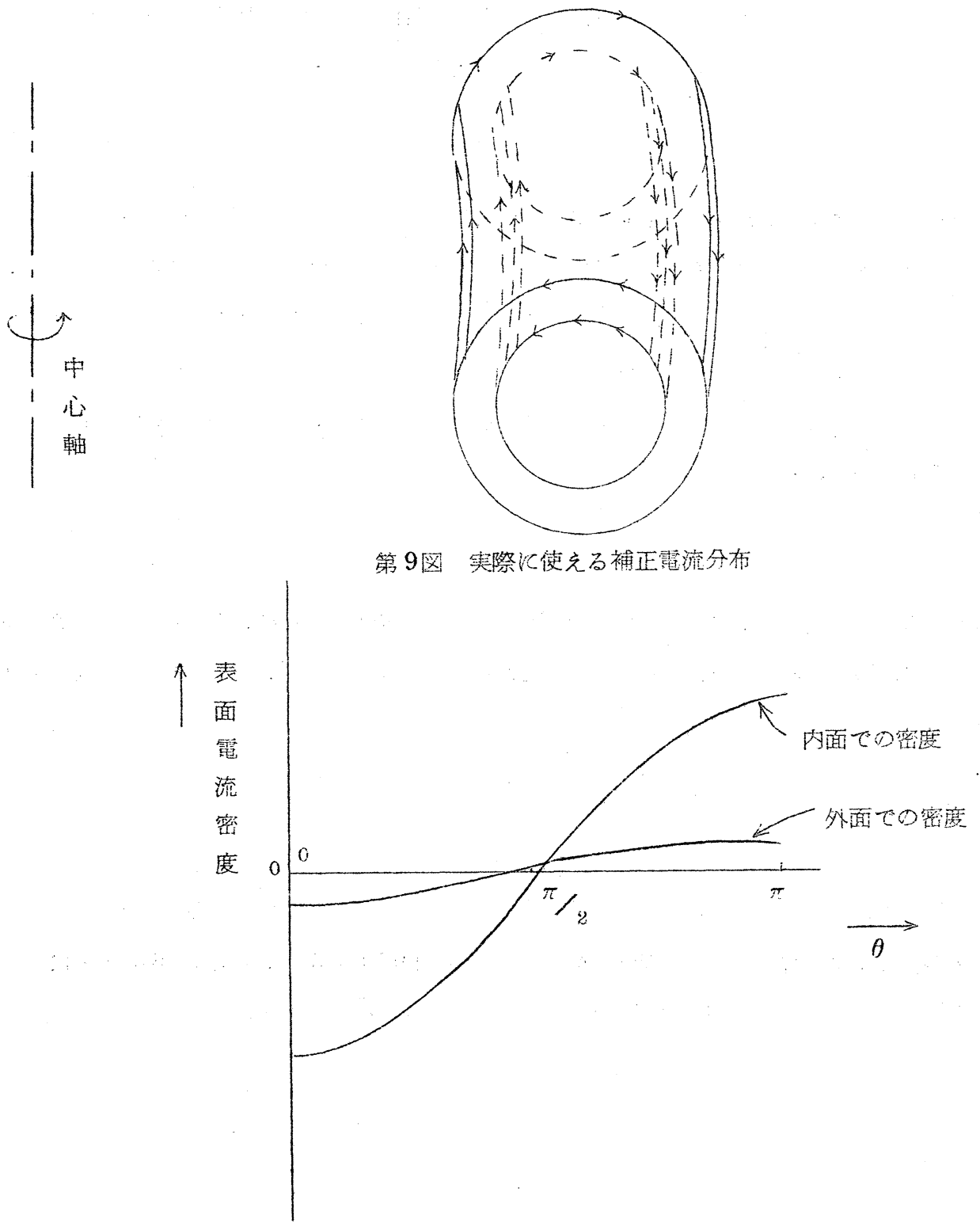

第 10 図 実際に使える補正電流密度 
ここで更に, 補正電流の外面での分布 (第9図, 第 10 図参照) は, 内面の分布飞比して, 小さ らととに注意しておく。特にシエルの形状が，円環電流が真空塨で作る磁気面に沿って形成され ている場合, 補正電流の外面での管流密度は零である。

ここに述べた管流分布は主として，中心面附近と，シエル切りロ附近に限られたくら形のもので ある。とのょうな補正コイルの設計計算は容易であり，製作もそれ任ど困難ではあるまい。このコ イル形状は，上下に测定のをめ開いたスペースを与える。

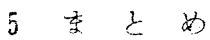

トカマク装監に通常昰るシエルギャツプ附近での磁境の乱れを除くた奶の二つの方法について述

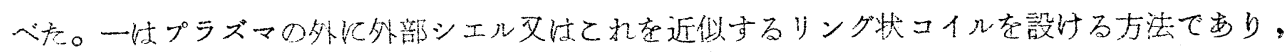
二はシエル附近に補正コイル設ける力法である後者は二つのくら形コイルを上下に向い合わせ を形老しており，大交测定用のスペースを上下に設けるととが出来る。このくら型コイルに流す

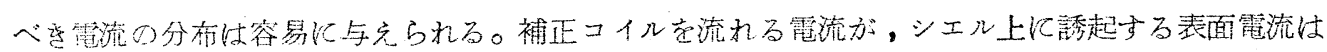
考慮に入えられてんる。

6 㟫 辞

ここに取报っ充内容は, 静网大学染谷太郎助教授, 原研核誘合研究空, 及びガルフジェネラルア トミック核瀜合研究室の諸氏との討論のうちに進的られたものですり,とてに上記の諸氏に感謝し kho

文㙴

1) M.A. Leontovich: Plasma physics and the problem of controlled thermonuclear Fusion Vol. 1 p.272-278 (Permgamon Press 1961)

2）染谷太郎，伊藤智之，日本物理学会核融合分科会 ( 1971 年 6 月，東京） $16 p-F-4$; subnitted to Japanese Joumal of Applicd Physics. 